DOI https://doi.org/10.18551/rjoas.2018-03.13

\title{
THE STRUCTURE DESIGN OF CUSTOMARY VILLAGE: A CASE STUDY IN PROBUR VILLAGE, ALOR REGENCY OF INDONESIA
}

\author{
Djaha Ajis Salim Adang*, Lake Primus \\ Faculty of Social and Political Sciences, Universitas Nusa Cendana, Indonesia \\ *E-mail: ajissalim@yahoo.com
}

\begin{abstract}
Village can be stipulated as a customary when it has four conditions, i.e. law community unit, shared value, customary governance institutions, and norms of customary law. The customary village structure does not require community organizations such as RW (neighborhood ward, Rukun Warga) and RT (neighborhood block, Rukun Tetangga) because each head of tribe directly controls his people very effectively based on the right of origin and customs. Indigenous peoples have their own custom rules or norms to honor abiding citizens and impose penalties or sanctions against disobedient people. The shared value in various affairs is a form of custom strength.
\end{abstract}

\section{KEY WORDS}

Structure design, customary village, social impact, community.

The Government of Indonesia has issued Law No. 6 of 2014 on Villages which require the Regency Government to re-arrange the status of villages into "Village" or "Customary Village" types. For the determination of customary villages, the present village should be assessed with reference to a number of conditions. A golden opportunity has been given. At the latest one year after the enactment of this Law, the Regional Government of Regency/City shall stipulate a Regional Regulation on the Establishment of Village and Customary Village in its territory. It is possible that the regency/city governments in East Nusa Tenggara will assign the present villages into a "village" and there is no "customary village". Of course, the people of East Nusa Tenggara who still have strong customs and traditional institutions will object it.

Many areas in East Nusa Tenggara still have traditional villages and traditional houses that have been published in foreign countries. This condition should be a preliminary description that there are still many villages with a governance structure based on local customs.

Based on the results of the first year of research (Djaha and Lake, 2015) and a number of previous studies (Djaha, et al, 2004, 2005, 2006, 2007), Probur Village is qualified to be a customary village. Therefore, a preparation to be a customary village is necessary. One of them is the arrangement of customary village structures. The problem is "How are the structure design of the customary village governance and the main task of each element of government?" This study aims to obtain the complete structure of customary village government with their respective duties. Organizing structures relates to authority, duties, functions, rights and obligations, and organizational structures of the customary village. Structure design needs to be done to adjust the main tasks, functions, authority, and rights and obligations with the very complex need demands of villagers.

The results of this study are expected to contribute to theoretical and empirical aspects. Theoretical aspects are related to reinforcement of the postmodernism theories and weakening the modernism theories. Besides, the results of this study are expected to contribute to organizational theory and organizational behavior, especially in organizational culture and organizational structure design. In the empirical aspect, the results of this study contribute to the certainty of the regency government of Alor to stipulate Probur Village as Customary Village. 


\section{LITERATURE REVIEW}

Customary village is a unit of community that has boundaries with the authority to regulate and manage the affairs of government, interests of the local communities based on the community's initiatives, right of origin, and/or traditional rights recognized and respected in the system of government of the Republic of Indonesia (Article 1 paragraph 1 of Law Number 6 of 2014).

Customs is part of the culture (Koentjaraningrat, 1987: 13). Furthermore, according to Koentjaraningrat (1987: 11-12), customs has four levels i.e. ideas or value systems or values, norms, legal systems, and specific rules. The fourth customs level to the first customs level is the most concrete level to the most abstract level.

Hilman Hadikusuma (2003: 105-106), quoting Ter Haar, states that the law community is a fixed and orderly group of people with own powers/self-government and concrete or intangible wealth. He argues that the customary law community still actually exists with their respective customary laws based on territorial or genealogical bonds, and/or a mixture of genealogical-territorial bonds. The Territorial Law Community is a fixed and orderly society whose members are bound to a certain territory, whether in the worldly connection as a place of life and in spiritual connection as a place of worship to the ancestral spirits. The territorial law community can be distinguished in three kinds: the Village Organization, the Regional Organization, the Village Association. The Genealogical Law Community is the unity of an orderly community in which its members are bound to a common lineage of one ancestor, either directly because of the blood relations or indirectly due to the marital affinity or customs affinity. In the Dutch East Indies era, the genealogical society was divided into three types, i.e.: patrilineal society, matrilineal society, and bilateral/parental society. The Territorial-Genealogical Law Community is the unity of a fixed and orderly society in which its members are not only bound to the particular territory but also attached to the hereditary relationship in the blood relations and/or kinship.

Organizational design deals with the overall organizational structure and plans to change the team's philosophy and orientation. This effort will provide a new structure of duties, authority, and interpersonal relationships that will reliably connect individual and group behaviors in improving work (Gibson, Ivancevich, Donnelly, 1996: 19). The organizational design considers the construction and changes the organizational structure to achieve organizational goals. Constructing and changing an organization is just like building or renovating a house (Robbins, 1994:7).

The structure design of customary village organization aims to accommodate traditional (native) and modern (village) governance in a structure that can ensure the integrative administration of state governance and customary governance and seek to reduce the conflict of indigenous people values and the state value. It is important to acknowledge that ethnic/traditional cultural dialogue with the state has constraints: First: the ability and firmness of cultural roots and the system of traditional values in the ethnic environment, Second: the nature or characteristic of the state value system that tends to be imperative to a value system assumed to prevent the establishment of a new value system. This condition is the nature or characteristics of imperative or hegemony, reigning not to be negotiable from the state value system. With such condition, can you imagine a dialogue situation with healthy take-and-give spirit between ethnic and state societies? (Umar Kayam in Sajono, 1999:72).

So far, both obstacles mentioned above are based on the community and government perspective, causing the cultural dialogue tends to be a cultural clash. If both survive but one of them is in a weak position, it will encourage the hypocrisy. Hypocrisy could be meant disagreement in the hearts, but agreement in the statements or the application of old habits behind the back. Indeed, the phenomenon of such attitudes and behaviors has been described by Fred W. Riggs (in Pamudji, 1993) in his theory of Sala Model with the characteristic of prismatic society i.e. overlapping society; a society that formally enjoys making rules, but in practice, they return to old habits. Riggs describes it as a transitional society. It seems that this theory is still valid today. The shift in values from patriarchy to 
democracy is not as easy as imagined. Formal structures that cannot accommodate leaders based on genealogical values bring up informal leaders in addition to the existing formal leaders. Community loyalty to their informal leaders is not loosened. Consequently, community participation in various government, development, and community activities controlled by formal leaders becomes disrupted.

Therefore, when designing the organization of the Village Government and filling the structure, it is necessary to consider the present cultural values in the community. David Kaplan in his Theory of Culture (2000: 102) suggests the need to pay attention to the concept of cultural ecology. A feature in cultural ecology is the concern about cultural adaptation on two levels: first, the cultural system adapts to its total environment, Second; the way institutions in a culture adapt. This cultural adaptation process is expected to create a synergism that can ensure the effectiveness of the structure design of customary village governance.

This process is called cultural acculturation. According to Ratna Dwi Lestari Ucridh, (2012) cultural acculturation is a process of cultural and psychological change shaped from intercultural meetings. The effects of cultural acculturation can be seen from the various levels of interacted cultures. At the group level, acculturation usually causes cultural, customs, and social institutions change. Acculturation requires a two-way process to make changes that through adjustment and adaptation by minorities such as indigenous peoples with the dominant majority such as the state.

\section{METHODS OF RESEARCH}

This study used a qualitative approach with an intrinsic case study (Stake in Denzin and Lincoln, 2009). This approach directed the researchers to investigate the customs that built the 'native village' governance structure in Probur Village. The data in this research were collected by depth interview, observation, and document. The informants were chosen purposively, i.e. the parties or the families of the parties directly involved in the implementation of 'native' village administration, the parties who have the ability to tell the history of the village like a traditional leader, and the parties that control the current village conditions such as religious leaders, educational leaders, village heads, and head of BPD (Village Consultative Body, Badan Permusyawaratan Desa). Data analysis included data categorization, data presentation, data verification, and data interpretation.

\section{RESULTS AND DISCUSSION}

A customary village is a unit of community that has clear territory, shared feelings in all their activities, customary governance institutions, and valid customary legal norms recognized by the Government (central, provincial, district/city). Customary governance institutions are manifested in the governance structure. Structure design is a process of designing structures by considering the division of work by function and geographical position, a chain of command, centralization, decentralization, and formalization which can support village governance, development, community development, and community empowerment.

The structure design of the native governance aims to preserve the important values based on the right of origin and to accommodate outside values to complement or replace those that are no longer appropriate to the present conditions. The structure of customary governance is led genealogically by brothers, the elder brother called Om'elor, the middle brother called Kpit'elor, and the youngest brother called Ik'elor. This structure applies at the tribal level, a combination of several tribes, and villages.

In Probur Village, there are three main tribes namely Bring, Aboa, and Panea. Each of these tribes then develops sub-tribes. Bring tribe becomes Bring, Duel, Madal, and Aluaben sub-tribes. Aboa tribe becomes Kabor and Kalon sub-tribes. Panea tribe becomes Braklel, Dohing, Molhan, and Dulel sub-tribes. The number of sub-tribes emerging from the main tribes depends on the number of sons born to the rulers of the tribe. It causes the variation 
number of sub-tribes below the main tribe. This traditional/native governance structure continues to develop in line with the development of tribes and sub-tribes within the village. The identified traditional governance structure of Probur Village (Djaha, et al., 2004, 2015, 2016) can be seen in Figure 1 below.

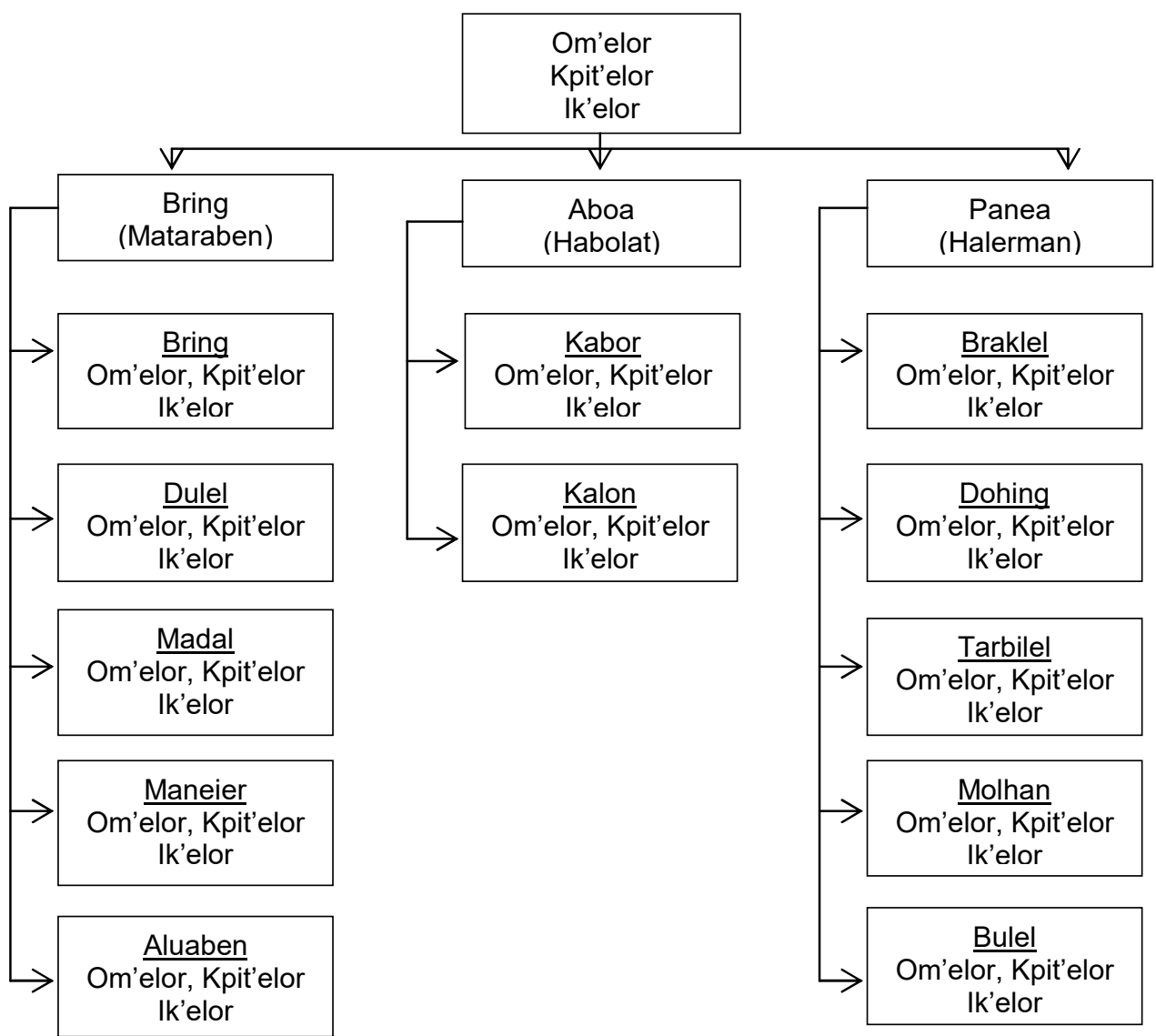

Figure 1 - The Native/Traditional Governance Structure in Probur Village

Table 1 - Duties of Traditional Government in Probur

\begin{tabular}{|c|c|}
\hline Government Elements & The duty of each element \\
\hline Or'elor & $\begin{array}{l}\text { Make general rules } \\
\text { Implement the government based on the rules } \\
\text { Implement judicial duties ik'elor and kpit'elor cannot accomplish } \\
\text { Make decisions at the last level } \\
\text { Encourage kpit'elor to carry out his duties properly } \\
\text { Control the implementation of rules and decisions at the kpit'elor and } i k^{\prime} e l o r \text { level } \\
\text { Give rewards or sanctions to kpit'elor for the success achieved or carelessness made. }\end{array}$ \\
\hline Kpit'elor & $\begin{array}{l}\text { Establish technical operational rules } \\
\text { Implement the government based on the rules made by om'elor and himself } \\
\text { Conduct judicial duties ik'elor cannot fulfill } \\
\text { Operationalize the decisions and plans made by om'elor } \\
\text { Follow up and implement all om'elor decisions } \\
\text { Motivate } i k^{\prime} e l o r \text { to carry out his duties properly } \\
\text { Control the implementation of rules and decisions at the } i k^{\prime} e l o r \text { level } \\
\text { Give rewards or sanctions to ik'elor for the success achieved or carelessness made. }\end{array}$ \\
\hline Ik'elor & $\begin{array}{l}\text { Establish village technical operational rules } \\
\text { Implement the government based on the rules made by om'elor, kpit'elor and himself } \\
\text { Carry out judicial duties on the problems faced by the community. } \\
\text { Guard om'elor } \\
\text { Protect the castle } \\
\text { Organize and lead the war } \\
\text { Follow up and implement all kpit'elor decisions }\end{array}$ \\
\hline
\end{tabular}

* The identification results of customs and customary institutions conducted by Djaha, et al. in Probur Village of Alor Regency, 2004, verified in 2015 and 2016. 
Both in the main tribes and the sub-tribes, there is the eldest son (om'elor), the middle son (kpit'elor), and the youngest son (ik'elor). Each of the sons in each tribe has his own duties. This unspoken division of duty is fixed in every tribe and has always been a tradition. Each position (om'elor, kpit'elor, and ik'elor) has its own duties.

Table 1 presents the duty description in each of the traditional 'village' government elements.

This basic structure and task are still functional although some tasks are no longer effective today, such as guarding om'elor is now more appropriate to accompanying om'elor, protecting the castle is more appropriate to protecting the village or known as civil defense (pertahanan sipil). Other tasks are considered still appropriate.

The value of the implementation of customary village government in Probur Village is the value of kinship (genealogical) underlying the shared value (solidarity) and compliance/loyal to the high rules. The strength of this value is also the underlying control of wealth in the village such as land, mamar $^{1}$ ), and customary forest, so that the wealth has more social than the individual value. The eldest is given the authority to regulate the use of the tribal wealth for the people. All head of the tribes knows their rights and obligations according to the prevailing customs. The head of the tribes has a high sense of belonging, the sense of belonging to his territory and the sense of belonging to his citizens. Thus, the control over the territory and wealth is used as much as possible for the prosperity of the people. This value is a differentiating sense of belonging to regional heads whose have no sense of belonging. Although Probur's people acknowledge that their customs are no longer complete, they still believe that the values still have the benefit such as 'bela' (customary oath) and 'karma"' (sanction for disobedience to customary oaths).

Bela has made Bring tribe, a newcomer tribe, as a tribal leader for Panea (a native tribe) tribe and Aboa tribe because Bring tribe is considered more powerful and capable. Thomas Loban of the Bring tribe was appointed the head of the Probur Village (1937), then the captain of Probur Village (1941), head of Probur's new village (1967), village coordinator (1969), and village head of Probur (1972-2007). During the election of the village head directly by the people of all villages in Indonesia, the village head of Probur was unelected but appointed by the Decree of the Regent from time to time until he handed over his position in 2007. Since 2007, the village head of Probur is elected every period, but the chosen candidate is always from the Bring tribe.

Every tribe in the Probur Village is hereditary according to the male (genealogical) lineage to date, although the village governance structure has changed since the promulgation of Law No. 5 of 1979. When compared to the current village governance structure, the head of the tribe is similar to the head of the hamlet. The loyalty level of customary community in each tribe to the head of the tribe is still very high when compared with the compliance to the head of the hamlet and the head of RW and RT. Thus, the structure of customary village governance in Probur Village is simple, as shown in Figure 2 below.

In the customary village of Probur, the village head is not directly elected but through the deliberation of the traditional leaders. Deliberation refers to a number of requirements that become the customs of Probur community. These conditions are (1) Direct descendants of the ruling tribe; (2) Adult males; (3) Be knowledgeable; (4) Be smart; (5) Be close with many people; (6) Have ability/skill (physical and mental); (7) Be polite/well behaved; (8) Have dragon spirit "(assertive and authoritative); (9) Be a wealthy and generous person. If the direct descendant of the ruling is not qualified, then the result of the deliberation can determine the second or third son. If they are still not qualified, they will consider the qualified

\footnotetext{
${ }^{1}$ Plantation with an area of 1-2 Ha which contains several types of long-life crops such as coconuts, pecans, areca nuts, betel nuts, coffee, bananas, and so on.

${ }^{2}$ Bela procedures for village leaders are those who pledge to drink the blood of each party mixed together with the ground and the fine wood from the handle of the sword used to cut the animals. Deviation from the customary oath results in death.

${ }^{3}$ Karma initially forms a certain type of disease, usually jaundice, if it is not immediately resolved-apologize to another party who once swore together - and kill the animal -usually a pig. The pig is then cooked and eaten together. When the ceremony is done correctly and on the basis of consciousness/sincerity, the person with the disease heals immediately or heals in a short time (several days: mostly three days).
} 
husband of the sister or a qualified male from another tribe. If the result of deliberation falls on the men outside the ruling tribe, the customary ceremony will be held to inaugurate the new village head as a part of the ruling tribe before the new rein of leadership is given.

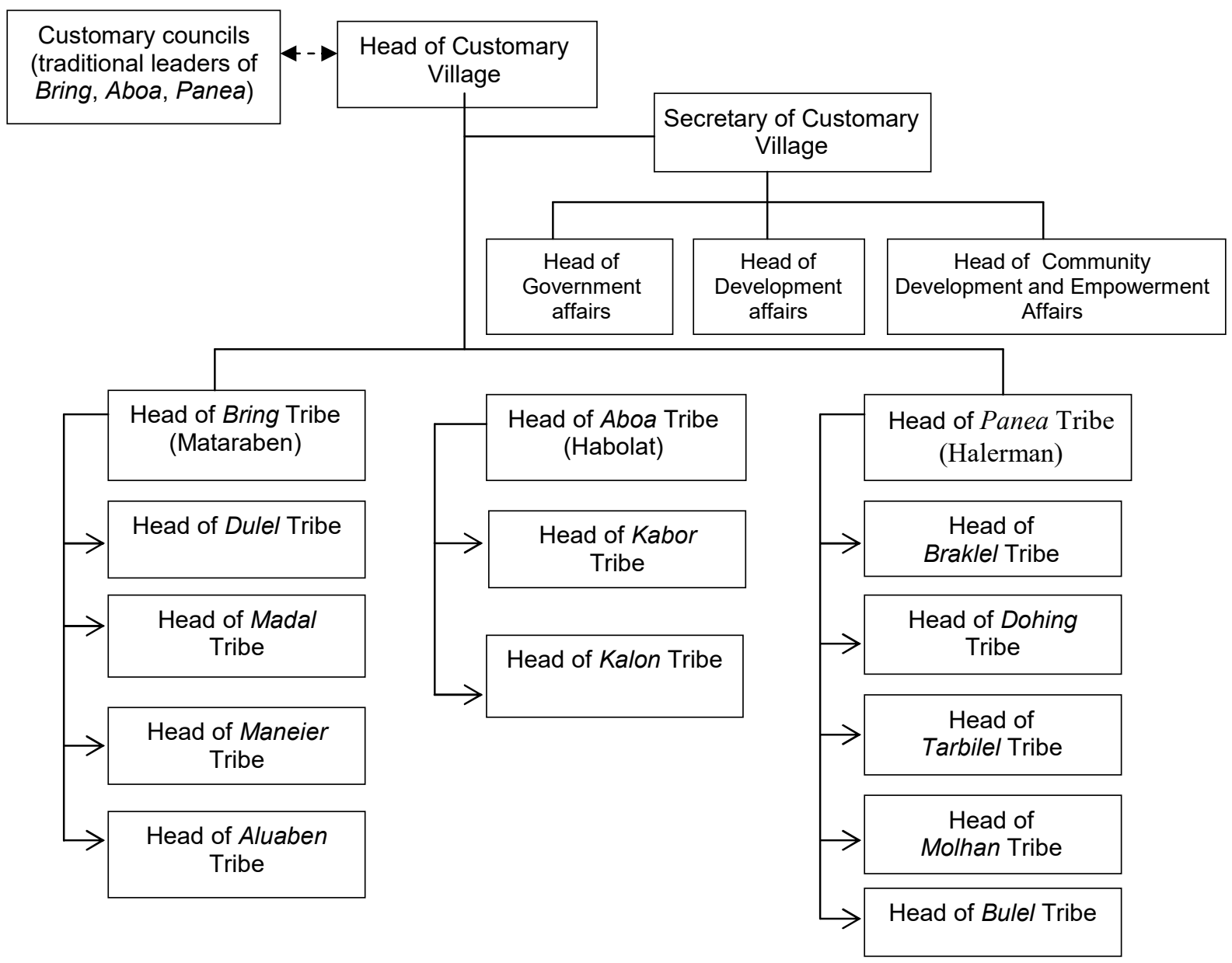

Bring, Aboa and Panea are the main tribes from which sub-tribes develop. The sub- tribe is the next generation calculated from the male lineage. Duel, Madal, Maneier, and Aluaben tribes are the sub-tribes of the main tribe of Bring. Kabor and Kalon are the sub-tribes of the main tribe of Aboa. Braklel, Dohing, Tarbilel, Molhan, and Bulel tribes are the sub-tribes of the main tribe of Panea. These sub-tribes are always evolving according to the growth of the sons within each tribe. Customary councils are traditional leaders from each of the main tribes and sub-tribes who conduct deliberation in appointing the head of the customary village, the rules of customary village, and as the judges in the customary court. The secretary and the heads of affairs in the customary village are staff members of the modern village government accommodated into the customary village governance structures to implement village governance, development, community development, and community empowerment in line with current government demands. Heads of tribes are the executing element that organizes the community based on the right of origin and local customs to implement village governance, development, community development, and community empowerment.

\section{Figure 2 - The Structure Design of Customary Village Governance in Probur Village}

The head of the tribe in each of the main tribes are the eldest sons of a direct descendant of the tribe. If he is not qualified enough, he remains the head of the tribe, but an assistant who performs daily tasks will be appointed. The assistant comes from the related tribe. This blood relationship keeps tribal people living in their own village or other villages will always be involved in their tribe affairs.

\section{CONCLUSION AND SUGGESTIONS}

The structure design of customary village is a process of reconstructing village structures into customary village structures. The structure design result of the customary village consists of the heads of customary village, the heads of main tribes, and the heads of sub-tribes. The village head is appointed through the deliberation results of the traditional 
leaders. The heads of main tribes are determined by the lineage of the eldest son in the tribe, both in the main tribe and the sub-tribes. Customary villagers are organized according to genealogical, not territorial, factors. Staff elements - the village secretary, the head of government affairs, the head of development affairs, the head of community development and empowerment affairs- are appointed by the head of the customary village.

The head of customary village is the result of the traditional council deliberation and is appointed through the traditional ceremony. The village head is not directly elected by the community. The heads of main tribes replace the heads of hamlets in the village governance structure and the heads of sub-tribes replace the heads of the RTs, without the heads of RWs. The heads of main tribes and the heads of sub-tribes rule the community based on the right of origin and the traditional rights in the implementation of village governance, development, community development, and community empowerment.

The village head is still assisted by staff elements, i.e. the village secretary, the head of government affairs, the head of development affairs, and the head of community development and empowerment affairs. This staffing element is adapted from the modern village government structure to organize the management of customary village governance. This combination is assumed to accommodate the elements of modern government and traditional government.

\section{REFERENCES}

1. Djaha, Ajis Salim Adang; Kamahi, Umrah; Panara, Arief; Kamahi, Syahlan. 2004. Identifikasi Adat Istiadat dan Lembaga-Lembaga Adat Yang Menunjang Pelaksanaan Otonomi Desa di Kabupaten Alor, Research Report, Kabupaten Alor dan Yayasan Swadeshi, Kupang, Indonesia.

2. Djaha, Ajis Salim Adang. 2004. Pemilihan Kepala Desa di Kabupaten Alor Berdasarkan Nilai Negara-Kebangsaan Versus Adat Istiadat Setempat, Jurnal Administrasi Publik, 3(5).

3. Djaha, Ajis Salim Adang; Wadu, Jacob; Lake, Primus. 2005. Pelaksanaan Otonomo Desa (Studi Kasus di Desa Soba Kecamatan Amarasi Barat Kabupaten Kupang), Jurnal Administrasi Publik, 4(1), October 2005, Kupang.

4. Djaha, Ajis Salim Adang; Wadu, Jacob; Lake, Primus. 2006. Persepsi dan Sikap Masyarakat Terhadap Refungsionalisasi Adat Istiadat Setempat Dalam Pemilihan Kepala Desa (Studi Kasus Persyaratan Pemilihan Kepala Desa di Desa Aimoli Kabupaten Alor, Jurnal Administrasi Publik, 5(1), October 2006, Kupang.

5. Djaha, Ajis Salim Adang; Wadu, Jacob; Lake, Primus. 2006. Kapasitas Desa Dalam Pelaksanaan Otonomi Desa Di Kecamatan Alor Barat Laut Kabupaten Alor, Jurnal Administrasi Publik, 5(1), October 2006, Kupang.

6. Djaha, Ajis Salim Adang; Wadu, Jacob; Lake, Primus. 2007. Desa Adat (Sebuah Upaya Penyelenggaraan Pemerintahan Desa Berdasarkan Adat Istiadat Setempat, Studi Kasus di Desa Bampalola Kecamatan Alor Barat Laut Kabupaten Alor), Jurnal Pluralis Jurnal Ilmu-IImu Sosial, 5(2), April 2007, Kupang.

7. Djaha, Ajis Salim Adang; Wadu, Jacob; Lake, Primus. 2015. Otonomi Desa Dan Hegemoni Negara Dalam Pemilihan Kepala Desa di Kabupaten Alor (Studi Kasus di Desa Probur dan Desa Alor Kecil ), Postgraduate Program, Universitas Nusa Cendana, Kupang.

8. Djaha, Ajis Salim Adang; Wadu, Jacob; Lake, Primus. 2015. Dari Desa ke Desa Adat, Studi Kasus di Desa Soba Kabupaten Kupang, Desa Probur Kabupaten Alor dan Desa Praibakul Kabupaten Sumba Timur, Universitas Nusa Cendana, Kupang.

9. Djaha, Ajis Salim Adang; Wadu, Jacob; Lake, Primus. 2016. Dari Desa ke Desa Adat, Studi Kasus di Desa Soba Kabupaten Kupang, Desa Probur Kabupaten Alor dan Desa Praibakul Kabupaten Sumba Timur, Universitas Nusa Cendana, Kupang.

10. Denzin, Norman K. \& Lincoln, Yvonna S. 2009. Handbook of Qualitative Research, Pustaka Pelajar, Yogyakarta. 
11. Gibson, James, L., Ivancevich, John, M., Donnelly, James, H. JR., 1996. Organisasi, Perilaku, Struktur, Proses, Jilid 1 Edisi Kedelapan. Translated by Nunuk Adiarni. Binarupa Aksara, Jakarta.

12. Hadikusuma, Hilman, 2003. Pengantar IImu Hukum Adat Indonesia, Mandar Maju, Bandung.

13. Kaplan, David \& Manners, A.A. 2000. Teori Budaya. Pustaka Pelajar, Yogyakarta.

14. Koentjaranigrat, 2002. Kebudayaan Mentalitas dan Pembangunan. Gramedia Pustaka Utama, Jakarta.

15. Kusuma, N., \& Agustina, Fitria (Eds.), 2003. Gelombang Perlawanan Rakyat - Kasuskasus Gerakan Sosial di Indonesia, Insist Press, Yogyakarta.

16. Pamudji, S., 1996. Ekologi Administrasi Negara, Bumi Aksara, Jakarta.

17. Robbons, Stephen, 2015. Teori Organisasi - Struktur, Desain, dan Aplikasi, Edisi 3, Alih Bahasa Jusuf Udaya, Arcan, Jakarta.

18. Amosir, Djamanat, 2013. Hukum Adat Indonesia, Eksistensi dalam Dinamika Perkembangan Hukum di Indonesia, Nusantara Aulia, Bandung.

19. Sarjono, Agus R (Ed.), 1999. Pembebasan Budaya-Budaya Kita, Gramedia, Jakarta.

20. Sosialismanto, Duto, 2001. Hegemoni Negara - ekonomi politik Pedesaan Jawa. Lapera Pustaka Utama, Yogyakarta.

21. Ucridh, Dewilestari Ratna. 2012. Akulturasi dan Inkulturasi Budaya, http://ratnadwilestari. blogspot.co.id/2012/11, accessed on October 19, 2017.

22. Wahono, Francis; Jhamtani, Hira; Winters, Jeffrey; Zakaria, R Yando. 2003. Gelombang Perlawanan Rakyat: Kasus-Kasus Gerakan Sosial di Indonesia, Insist Press, Yogyakarta. 